\title{
Effects of cold exposure on Tenebrio molitor (Coleoptera: Tenebrionidae) pupal period, proportion of adult emergence, weight and deformation percentage
}

\author{
Evrim Sönmez \& Yeşim Koç
}

Sönmez, E. \& Koç, Y. 2019: Effects of cold exposure on Tenebrio molitor (Coleoptera: Tenebrionidae) pupal period, proportion of adult emergence, weight and deformation percentage. — Entomol. Fennica 30: 43-48. https://doi.org/ 10.33338/ef.79905

Low temperatures affect many life history traits of insects. The purpose of this study was to assess the effects of duration of cold exposure on the length of Tenebrio molitor's pupal period, proportion of adult emergence, adult weight and proportion of deformed adults. The trials were conducted in a laboratory in constant conditions with wheat flour and whole-wheat flour meal were used as food. Cold-exposed groups were achieved by exposing pupae taken on the first day after pupation for $1,3,5,10$ and 15 days at $+4{ }^{\circ} \mathrm{C}$. The results showed that as the period of cold increased, pupal period extended and proportion of deformed adults increased whereas there were no or less straightforward effects on adult weights and proportion of emerged adults, respectively.

E. Sönmez \& Y. Koç, Sinop University, Faculty of Education, Division of Mathematics and Science Teaching, Department of Science Teaching, Korucuk Mevkii, 57000,Sinop,Turkey.E-mails: esonmez@sinop.edu.tr,ykoc@sinop.edu.tr

Received 27 March 2018, accepted 5 November 2018

\section{Introduction}

Tenebrio molitor Linnaeus (Coleoptera: Tenebrionidae) is a beetle, which harms stored products globally. On the other hand, it is also a sustainable alternative protein source obtained from animals. It is thought that the increase in the world human population increases the demand of alternative protein resources ( $\mathrm{Ng}$ et al. 2001, Li et al. 2013). Another important point is that T. molitor is used as a natural feed source for poultry and fish (Van Huis et al. 2013, Özcan 2014, Tekeli 2014, Adámkova et al. 2017, Çalışlar 2017, Işık \& Kirkpinar 2017).

In the above contexts, it is useful to have specific information about the conditions, where the species can or cannot thrive well. For example, low temperature affects insects in many ways, including survival rate, adult emergence rate, developmental time, fecundity and deformation percentages (deformation: adults not having wings at all, having inwardly or outwardly convoluted wings or having deficient wings) (Li \& Otvos 1998, Kalyoncu et al. 2005, Levie et al. 2005, Taşkın \& Ergin 2013).

The temperatures that insects need for their pre-adult development and to maintain their adult lives differ according to species. As in other living beings, low or high temperatures cause significant physiological reactions in insects. Those reactions are among the most important adaptations they have for surviving under changing environmental conditions. As temperature decreases, insects gradually lose some of their abilities of fly- 
ing, developing, feeding etc. Eventually, when the nervous system and muscles no longer function, the whole organism becomes inactive. These functions can be reversed, if the temperature is not too cold (or warm) and the period of exposure is not too long.

In the study conducted by Koo et al. (2013) with $T$. molitor, beetles were reared at six different temperatures. They found that the developmental period decreased with increasing temperature as can be expected for poikilotherms up to species-specific limits. In the study conducted by Allen et al. (2012) with T. molitor and Cyrtobagous salviniae Calder \& Sands, they found that these beetles could have a limited ability to respond in a short time to temporary temperature changes. Instead, they could make behavioural adjustments to avoid high temperatures. As temperature decreases and exposure time increases, negative effects become irreversible and fatal.

T. molitor is one of the species, which is reared as natural food source for poultry and fish. If there is low demand from customers, then producers of T. molitor put them in the fridge and sell them later. This leads customers to get deformed adults or low egg quality depending on the length of cold storage (Punzo \& Mutchmor 1980, Jian et al. 2015). In addition, when there are abundantly insects in a laboratory stock, researchers keep $T$. molitor in the fridge and use them later. As a consequence, the use of such adults for other studies may also lead to incorrect results (Levie et al. 2005).

For all the above reasons, the purpose of this study is to determine the effects of duration of cold exposure during pupal stage on the duration of pupal stage, proportion of adult emergence, adult weight and proportion of deformed adults. With this knowledge, researchers and growers, who practise mass production of $T$. molitor, can obtain higher quality and highly productive insects.

\section{Materials and methods}

\subsection{Trials}

In our study, we used mealworm T. molitor, which was reared at least for five generations in
Sinop University Faculty of Education Biology Laboratory. Effects of cold exposure applied to $T$. molitor pupae on pupal period, proportion of adult emergence, adult weight and proportion of deformed adults were investigated. The trials were conducted under laboratory conditions of $27 \pm 2{ }^{\circ} \mathrm{C}$ temperature, $60 \pm 5 \%$ relative humidity and continuous dark. Wheat flour and wholewheat flour were used as feed for T. molitor larvae and adults.

The studies first started with rearing insects with a feed medium, which was created by mixing $1 / 1$ wheat flour and whole-wheat flour. The insects were reared in plastic containers (size $30 \times 20 \times 5 \mathrm{~cm}$ ). Wood dust was added in the containers to ease movement on the foodstuff. Small pieces ( 2 for each container, $4 \times 4 \times 6 \mathrm{~cm}$ ) were cut from egg boxes for providing convenience for adults to mate and lay eggs. While the plastic containers were covered to prevent entrance of other living beings, small holes were opened on the top side to enable gas exchange.

Potato was used for humidity $(3 \times 3 \times 3 \mathrm{~cm})$. They were wrapped into aluminium foil in order to prevent their contact and moisturing and decaying the food. The pieces of potato were changed every $3 \mathrm{~d}$ for the food layer not to get mouldy. The food layer was adjusted $4-5 \mathrm{~cm}$ thick. The food was renewed with intervals of $10 \mathrm{~d}$. The larvae in the old food were separated by using a sifter and they were transferred on the new food.

The containers were checked every day. As soon as the larvae had pupated, they were placed in Petri plates $(9 \times 1.5 \mathrm{~cm})$ and exposed to cold $\left(4{ }^{\circ} \mathrm{C}\right)$ for different periods $(1,3,5,10$ and $15 \mathrm{~d}$, refrigerator 5007HD, Arçelik-Turkey).

The groups whose cold exposure ended were brought to the laboratory, where the further experiment was performed. Petri plates were observed every day and the period from pupae to adulthood was recorded. At each adult emergence, the pupal period was calculated. All the pupae, which did not emerge were recorded and proportion of adult emergence was calculated. Emerged adults were weighed immediately. The adults were examined one by one and the deformed ones were recorded. The trails were repeated three times for each cold treatment with 15 insects in each replicate. 
Fig. 1. Means \pm SDs of pupal periods of coldstored Tenebrio molitor pupae. Differences between the cold treatments with the same lower-case letter are notsignificant $(p>0.05$, Mann-Whitney U tests) ( $n=3$ for each duration of cold exposure, each an average of 15 individuals).

\subsection{Data analysis}

Average data were obtained of the 15 insects for each of the three trials (total of 45 insects) for each cold treatment, yielding three averages of 15 insects per treatment, which were used in statistical analyses as independent replicates $(n=3$ in each cold treatment).

The study design is for one-way ANOVA with the duration of the cold exposure as a treatment variable. One-way ANOVAs could be performed for adult weights and deformation percentages, because, according to Levene's tests, the residual variance of the ANOVA model was not heteroscedastic for neither of those variables.

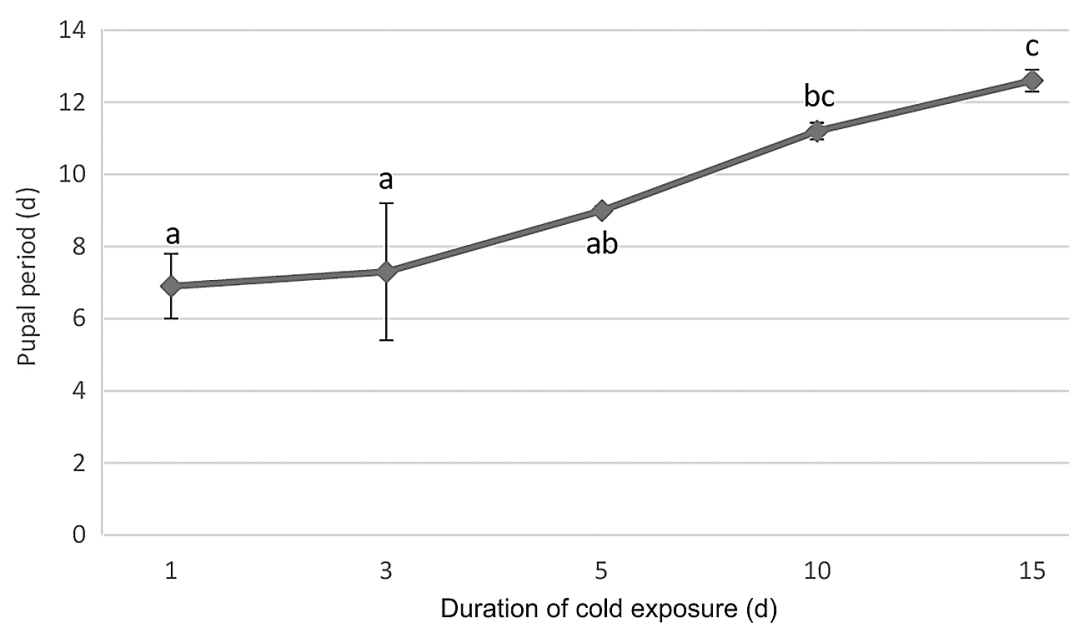

For these variables, Tukey HSD test was used after a significant treatment effect in ANOVA in order to find out differences among the five treatment levels (different durations of the cold exposure).

In contrast, heteroscedasticity was found both for residuals of the length of pupal periods and proportions of adult emergence. Therefore, Kruskal-Wallis tests were used for these variables, and if a significant treatment effect was found, Mann-Whitney U tests were used to find out pairwise differences among the treatment means.

SPSS 21.0 program was used in all statistical analyses.

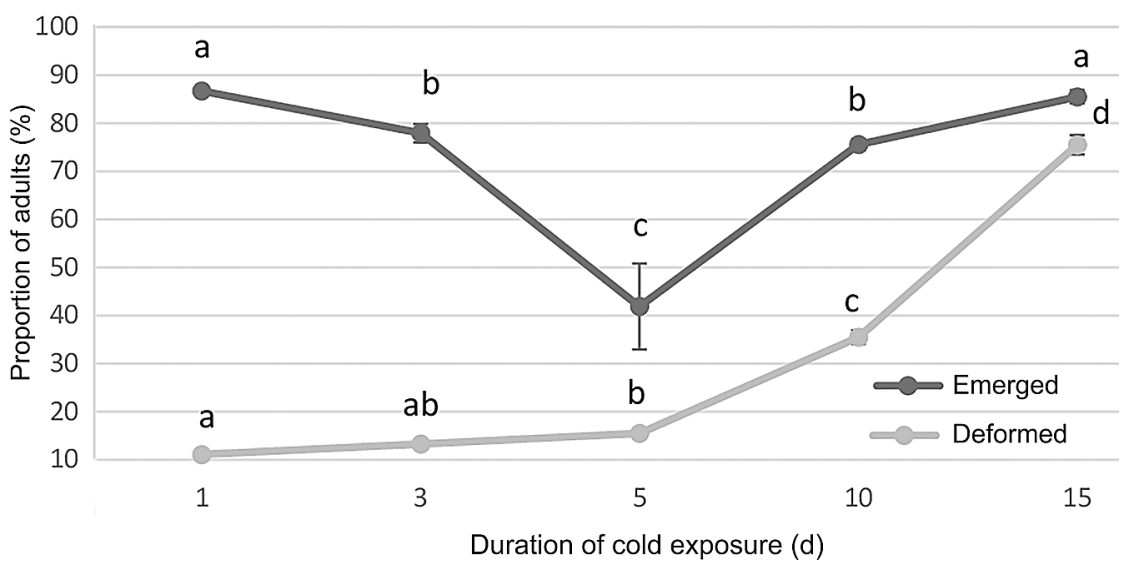

Fig. 2. Means \pm SDs of proportions of emerged and deformed adults of cold-stored Tenebrio molitor pupae. Differences between the cold treatments with the same lowercase letter are not significant $(p>0.05$, Mann-Whitney $U$ tests for proportion of emerged adults, Tukey HSD test for deformation percentage) ( $n=3$ for each duration of cold exposure, each an average of 15 individuals). 


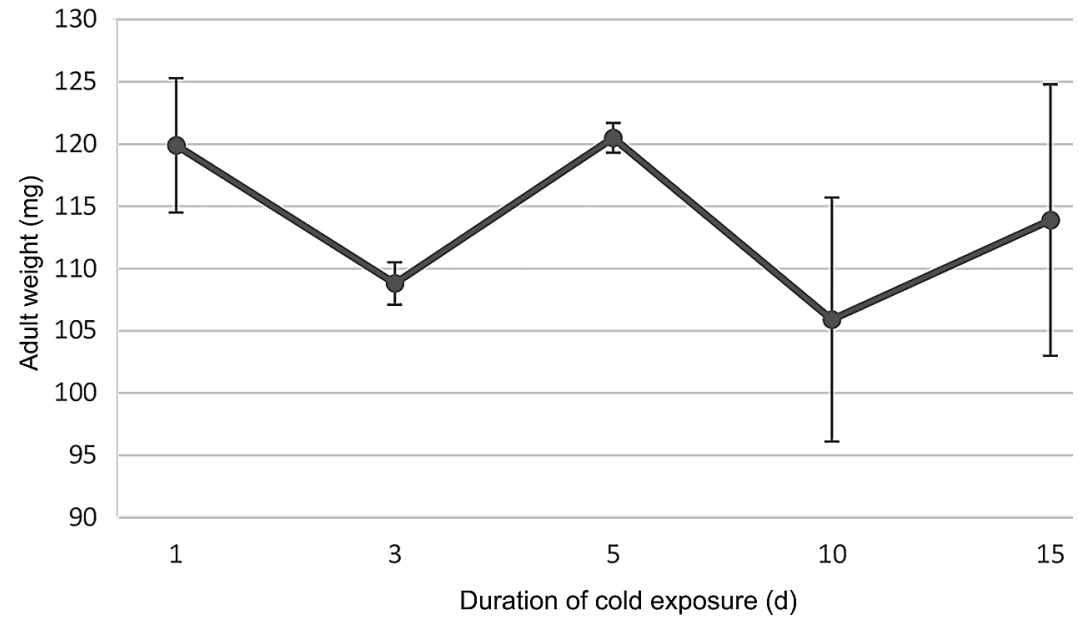

Fig. 3. Means \pm SDs of adult weights of coldstored Tenebrio molitor pupae. There were no significant differences among the cold treatments $(n=3$, for each duration of cold exposure, each an average of 15 individuals).

\section{Results}

The length of pupal period and adult deformation percentages increased with the increase of the duration of the cold treatment (length of pupal period: Fig. $1 ; H=58.9, p<0.001, d f=4$; adult deformation percentage: Fig. 2, $F_{4,10}=1421.6, p<$ $0.001)$. Proportion of adult emergence first decreased from 1 to 5 days but then increased from 5 to 10 days of cold treatment (Fig. $2 ; H=13.2, p=$ $0.010, d f=4)$. Adult weights were not significantly influenced by the cold treatment (Fig. 3; $F_{4,10}=2.53, p=0.11$ ).

\section{Discussion}

As in other living beings, low or high temperatures cause significant physiological reactions in insects (Khalid et al. 2014). While more flexible responses of $T$. molitor can be involved in extreme conditions during the pupal stage, eggs or young larvae are more sensitive (Punzo \& Mutchmor 1980, Riberio 2017). In case of temperatures below $+10{ }^{\circ} \mathrm{C}$, a stressful situation occurs for T. molitor and cold coma temperature is $+7{ }^{\circ} \mathrm{C}$ (Punzo \& Mutchmor 1980, Jian et al. 2015). In low temperatures, insects have different adaptations in order to survive. One of these is the water loss, which has evolved against changes, which can occur in low temperature (Taşkın \& Ergin 2013). In the present study, the delay in adult emergence as the period of exposure to cold increased (Fig. 1) could be a result of water loss as found by Punzo (1975) in a study of T. molitor. However, then one would have expected a decrease in pupal weight with longer exposure to cold in the present study, which was not the case (Fig. 3).

In the present study, the proportion of adult emergence decreased until $5^{\text {th }}$ day and then increased with the duration of cold exposure (Fig. 2.), whereas the proportion of deformed adults increased along the whole range of the duration of low temperature (Fig. 2). Of the pupae, which were exposed to cold for 15 days, $75.5 \pm 2.0 \%$ did not emerge and died, whereas there were considerably and increasingly less deformed adults as the duration of the cold treatment shortened. This situation may result from the fact that as the time inside pupa increased, the mechanisms to cope with cold temperatures did not work.

In another study conducted with $T$. molitor, Bowler (1967) stated that the decrease in physiological performance can result from a characteristic of all holometabolous insects that they are sensitive to temperature changes during metamorphosis in the pupal stage. Taşkın and Ergin (2013) conducted a study on the effects of low temperature and female parasitoid age on the ratio of adult emergence and length of pupal period of Itoplectis melanocephala (Gravenhorst) reared in Galleria mellonella (Linnaeus). They found that length of pupal period increased in pupae exposed to low temperature $\left(1,4,7\right.$ days at $\left.+4{ }^{\circ} \mathrm{C}\right)$ and adult emergence percentages decreased; however, no deformation was found in adults.

In insects, especially the fat tissue is depleted 
during starvation when they are exposed to low temperature (Nurullahoğlu \& Kalyoncu 2000, Arrese \& Soulages 2010). Accordingly, there are studies reporting a weight loss in insects, which are exposed to low temperature. Nurullahoğlu and Kalyoncu (2000) acclimated G. mellonella pupae at $+4{ }^{\circ} \mathrm{C}$ for 10,20 and 30 days and they found weight loss and decrease in total lipid and total fat acid percentages with the extension of the exposure time.

However, in our present study, no significant differences were found in adult weights of beetles exposed to cold $\left(+4{ }^{\circ} \mathrm{C}\right)$ for different time periods (Fig. 3). In a study conducted on Cnephasia jactatana Walker by using three different temperatures $\left(15,20\right.$ and $\left.25^{\circ} \mathrm{C}\right)$, Ochieng-Odero (1992) found higher weights in females reared at $15^{\circ} \mathrm{C}$ than 20 and $25^{\circ} \mathrm{C}$. The reason for that may be that the insects at $15^{\circ} \mathrm{C}$ have a slower developmental rate. Therefore, they do not have enough time to use their reserves, while those at higher temperatures have already depleted much of their reserves.

In insects, increasing temperatures generally speed up the ovulation rate, egg number and larval developmental stages and decreases adult life. In agreement with that, in a study conducted with T. molitor by using six different temperatures (from $15^{\circ} \mathrm{C}$ to $30^{\circ} \mathrm{C}$ ) and the $14 \mathrm{~L}: 10 \mathrm{D}$ light condition, Koo et al. (2013) reported that larval development period decreased with the increase in temperature. Kim et al. (2015) suggested that the optimal rearing temperature of $T$. molitor, which they produced massively, was $17.0-27.5{ }^{\circ} \mathrm{C}$, whereas that of the hatching rates and length of the egg periods was $25-27.5{ }^{\circ} \mathrm{C}$. Considering flexibility of time schedules of delivering beetles for customers and total weight of produced beetles, the effective condition was mass-breeding at $25{ }^{\circ} \mathrm{C}$.

In a study on G. mellonella (Kalyoncu et al. 2005), the cold acclimation was brought about gradually (temperature lowered from $25^{\circ} \mathrm{C}$ to 15 , $12,10,8,6$ and $4{ }^{\circ} \mathrm{C}$ on $5,6,7,8$ and $11 \mathrm{~d}$ after pupation, respectively, and maintained at the $4{ }^{\circ} \mathrm{C}$ up to day 30 , i.e. to the end of the exposure [samples 17,23 and $30 \mathrm{~d}$ after pupation were from this period of $\left.\left.4{ }^{\circ} \mathrm{C}\right]\right)$. The adult emergence decreased with a longer exposure to cold, so that no adults emerged in the treatments with the longest expo- sure periods ( 23 and $30 \mathrm{~d}$ ). When compared to the control group (constant temperature $25^{\circ} \mathrm{C}$ ), the adults, which emerged in the $11 \mathrm{~d}$ and $17 \mathrm{~d}$ exposures, were small and some had convoluted wings. In our present study, the proportion of adult emergence was found to be similar in the pupae exposed for $1 \mathrm{~d}$ and $15 \mathrm{~d}$ and also in the pupae exposed for $3 \mathrm{~d}$ and $10 \mathrm{~d}$, and higher in all of those cases compared to the $5 \mathrm{~d}$ exposure (Fig. 2). More consistently, deformation percentages increased with the duration of the cold exposure (Fig. 2).

Since rearing of $T$. molitor is needed in many studies and applied contexts, they are kept in a refrigerator by researchers and growers when necessary. However, as increase in the period of waiting in the cold will cause changes in the traits of the beetles, storage in cold is not unequivocally suitable for this insect, depending of the purposes of the rearing.

Acknowledgements. We are grateful to Alp Erilli, Sivas University- Department of Statistics-Turkey, for the analysis of data and two anonymous reviewers for helpful comments on the manuscript.

\section{References}

Adámková, A., Adámek, M., Mlèek, J., Borkovcová, M., Bednáøová, M., Kouøimská, L., Skácel, J. \& Vítová, E. 2017: Welfare of the mealworm (Tenebrio molitor) breeding with regard to nutrition value and food safety. - Potravinarstvo Slovak Journal of Food Sciences 11(1): 460-465. doi: https://doi.org/10.5219/779

Allen, J. L., Clusella-Trullas, S., \& Chown S. L. 2012: The effects of acclimation and rates of temperature change on critical thermal limits in Tenebrio molitor (Tenebrionidae) and Cyrtobagous salviniae (Curculionidae). - Journal of Insect Physiology 58: 669-678. doi: https://doi.org/10.1016/j.jinsphys.2012.01.016

Arrese, E. L. \& Soulages J. L. 2010: Insect fat body: energy, metabolism, and regulation. - Annual Review of Entomology 55: 207-225. doi: https:/doi.org/ 10.1146/annurev-ento-112408-085356

Bowler, K., 1967: Changes in temperature tolerance with adult age in Tenebrio molitor. - Entomologia Experimentalis et applicata 10(1): 16-22. doi: https:// doi.org/10.1111/j.1570-7458.1967.tb00040.x

Çalışlar, S. 2017: Nutrient content of mealworms (Tenebrio molitor L.) and the utilization possibilities in poultry nutrition - Nevşehir Bilim ve Teknoloji Dergisi 6: 226-232. [In Turkish with English abstract.]

Işık, Ö. \& Kırkpınar, F. 2017: Etlik Piliçlerin Beslenmesinde Böceklerin Kullanılması. — Türk Tarım / Gıda 
Bilim ve Teknoloji Dergisi 5(7): 750-756. [In Turkish with English abstract.]

Jian, F., Fields, P. G., Hargreaves, K., Jayas, D. S. \& White, N. D. G. 2015: Chill-coma and minimum movement temperatures of stored-product beetles in stored wheat. - Journal Economical of Entomology 108(5): 2471-2478. doi: https://doi.org/10.1093/jee/tov196

Kalyoncu, L., Üstüner, T. \& Aktümsek, A. 2005: Farklı Sicaklık Derecelerinin Galleria mellonella (L.) Puplarının Açılma Oranına Etkileri. — Selçuk Üniversitesi Fen Edebiyat Fakültesi Fen Dergisi 26: 71-74. [In Turkish with English abstract.]

Kim, S. Y., Lee, Y. B., Park, J. B. \& Kim, N. J. 2015: Growth characteristics of mealworm Tenebrio molitor. - Journal of Sericultural and Entomological Science 53(1): 1-5. doi: https://doi.org/10.7852/jses. 2015.53.1.1

Koo, H., Seon-Gon, K., Hyung-Keun, O., Jung-Eun, K., Duck-Soo, C., Do-Ik, K. \& Iksoo, K. 2013: Temperature-dependent development model of larvae of mealworm beetle, Tenebrio molitor 1 . (Coleoptera: Tenebrionidae). - Korean Journal of Applied Entomology 52(4): 387-394. doi: https://doi.org/10.5656/KSAE. 2013.11.0.066

Levie, A., Vernon, P. \& Hance, T. 2005: Consequences of acclimation on survival and reproductive capacities of cold-stored mummies of Aphidius rhopalosiphi (Hymenoptera: Aphidiinae). - Journal of Economical Entomology 98(3): 704-708. doi: https://doi.org/ 10.1603/0022-0493-98.3.704

Li, L., Zhao, Z. \& Liu, H. 2013: Feasibility of feding yellow mealworm (Tenebrio molitor L.) in bioregenerative life support systems as a source of animal protein for humans. - Acta Astronautica 92: 103-109. doi: https://doi.org/10.1016/j.actaastro.2012.03.012

Li, S. Y. \& Otvos, I. S. 1998: Effects of storage on adult emergence and fecundity of Choristoneura occidentalis (Lep: Tortricidae). - Journal of the Entomological Society of British Columbia 95: 3-7.

Ng, W. K., Liew, F. L., Ang, L. P., \& Wong, K. W. 2001: Potential of mealworm (Tenebrio molitor) as an alternative protein source in practical diets for African catfish, Clarias gariepinus. - Aquaculture Research 32(1): 273-280. doi: https://doi.org/10.1046/j.1355557x.2001.00024.x
Nurullahoğlu, Z. Ü. \& Kalyoncu, L. 2000: Düşük sıcaklığın Galleria mellonella (L.) (Lepidoptera: Pyralidae) puplarının total lipid ve total yağ asidi yüzdelerine etkileri. - Selçuk Üniversitesi Fen-Edebiyat Fakültesi Fen Dergisi 1(16): 91-93. [In Turkish with English abstract.]

Ochieng-Odero, J. P. R. 1992: The effect of three constant temperatures on larval critical weight, latent feding period, larval maximal weight and fecundity of Cnephasia jactatana (Walker) (Lepidoptera: Tortricidae). Journal of Insect Physiology 38(2): 127-130. doi: https://doi.org/10.1016/0022-1910(92)90041-B

Özcan, M. A. 2014: Kanatlı hayvanların beslenmesinde kullanılan yeni alternatif protein kaynakları. - Türk Tarım - Gida Bilim ve Teknoloji Dergisi 2(2): 66-70. [In Turkish with English abstract.]

Punzo, F. 1975: Effects of temperature, moisture and thermal acclimation on the biology of Tenebrio molitor (Coleoptera: Tenebrionidae). — Retrospective Theses and Dissertations. 5438. PhD thesis, Iowa State University, USA.

Punzo, F. \& Mutchmor, J. A. 1980: Effects of temperature, relative humidity and period of exposure on the survival capacity of Tenebrio molitor (Coleoptera: Tenebrionidae). - Journal of The Kansas Entomological Society 53(2): 260-27.

Riberio, N. T. G. M. 2017: Tenebrio molitor for food or feed. Rearing conditions and the effect of pesticides on its performance. - ESAC (Escola Superior Agraria, Politecnica de Coimbra) 1-70.

Taşkın, D. \& Ergin, E. 2013: Düşük sıcaklık ve yaşın Itoplectis melanocephala (Gravenhorst) (Hymenoptera: Ichneumonidae) erginlerinin çıkış oranı, süresi, sayısı ve eşey oranına etkileri. - Adıyaman Üniversitesi Fen Bilimleri Dergisi 3(1): 38-48. [In Turkish with English abstract.]

Tekeli, A. 2014: Hayvan beslemede alternatif protein kaynağı olarak böceklerin kullanımı. - Türk Tarım ve Doğa Bilimleri Dergisi 1(4): 531-538. [In Turkish with English abstract.]

Van Huis, A. V., Itterbeeck, J. V., Klunder, H., Mertens, E., Halloran, A., Muir, G. \& Vantomme, P. 2013: Edible insects: Future prospects for food and feed security. - Food and Agriculture Organization of the United Nations, Forestry Paper 171. Rome, Italy. 